\title{
邦產すげ屬植物ノ葉ノ解剖分類學的研究 XVIII
}

\author{
秋山茂雄
}

Shigeo Akiyama: On the Systematic Anatomy of the Leaves of Some Japanese Carices. XVIII.

Received October 25, 1938.

本稿二記スルハなきりすげ節（Sect. Graciles）二屬スル諸種,郎チなきりすげ,せ んだレすげ，てでめなきりすげ，じんぐうすげ，むにんなきりすげ，お痤なきりす げ，たかさでるさなきり及ビふさなきりすげニ於ケル觀察結果ナリ。之等八互二極 メテ相似タル形狀フ示スフ以テ各自間ノ識別ヨナス八困難ナレドモ，共通ニ見ラル 、特徵ニ至りテハ他ノ節ニ屬スルモノ二比シ極メテ顯著ニシテ，以テすげ中ノ獨立 シタル一區フ形成スルト見ルベク，マタ外部形態二於テモ他種ト大ナル相違アリ，更 二之等諸種ガ大概秋日開花シ,他ノ殆ド全部ノすげガ春夏ノ候二開花スト異ナリ，コ レヨ以テソノ獨立性习維持セル所以ナリトモ解釋シ得ベシ。

共通セル著シキ特徵フ擧グレバ次ノ如シ。

蝶番細胞入中央部ラナスー條トソノ外側习ナス左右ノ各く一條, 即チ三條ヨ以テ 成リ，中央部ノモノ八 3-10 列ノ細胞ヨリナリ，各細胞八長方形ニシテ波狀屈曲膜 ヨ有スル事最モ多ク中間細胞卜類似セル形ヨナシ中二披針形，長嘴，銳尖ノ刺狀細

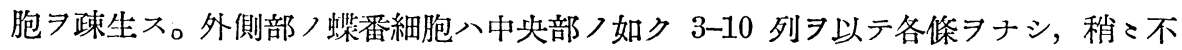
齊形习ナシ多角形, 方形乃至長方形ニシテ細胞膜八厚質二シテ波狀屈曲スルカ又八 全クセズシテー般ノすげニ見ラル、蝶番細胞卜類似ス。中閒細胞八一般二小形。脈 上細胞入表面二數ケ所，裏面ニハソノ約倍數アリテ一般二廣範圍习領シ，但シソノ 形狀ハソノ面ノ中間細胞ト大差ナキコト多シ。氣孔八椭圓形乃至圓棈圓形，長サ 25-30 $\mu$, 幅約 $25 \mu$ 。刺狀細胞八蝶番細胞中央部 >他二八表裹面脈上細胞條附近, 榄 番細胞二接スル表面中間細胞上，緗邊等ニアリテ卵形乃至披針形ニシテ通例鈍頭ナ リ。切斷面ニテ觀察スル時八蝶番細胞ハソノ中央部位ニテ凸形フナシ外側部位ニテ 八凹形フナス。葉片八下面平坦上面凸形フナシ先端微二外轉ス。維管束八幅廣キ横 斷面习示ス纎維組織习表裏面表皮直下二迄達スルモノ左右片卜モ數個所宛アリテソ ノ中最大ナルハ左右片中央部ノモノト中肋部ノモノナリ，更二之等ノ維管束間二八

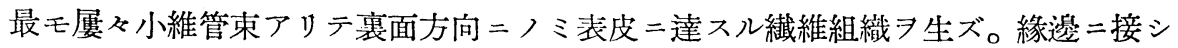
タル小維管束下面及ビ表面表皮下, 維管束二附隨セザル繊維組織ハトモ二表皮下二 著シク幅廣ク行キ亘り爲二表皮上二八著シク多數列ヨナス脈上細胞 呈セシム。

以上ノ中蝶番細胞條ガ中央卜外侧ノ三條

本報告以下十數報入東照宮三百年祭記念會ノ補助金ヨ得テコレアナセリ。コ、闰會二染 甚,謝意 表ス。 
示シ，就中緣邊二接スル表裏面表皮下ノモノガ著シク幅廣キ點ニ於テ本節ニノミ共 通セル最モ著シキ特徽トナスヨ得。

各種入夫ネ多少ノ相違點ヨ有スト雖モ，ソノ差極メテ小ナリ， ヨリテ以下二各種 ヘツキ前述ノ共通特徵ヨ除キタル諸點ヨ列記スルニ止ム。

なきりすげ Carex Nakiri OHwI in Acta Phytotax. et Geobot. 5 (1936) 64 (第一圖)。

表面表皮 蝶番細胞中央部ノモノ八長サ 20-60 $\mu$, 幅 $20 \mu$ 弱, 外側部ノモノ八略 々同大，不齊形，厚膜，中間細胞八長步 30-80 $\mu$ ，幅 $25 \mu$ 內外，厚膜，脈上細胞八 一二ノ大脈中央部 $=$ テ長サ 20-30 $\mu$ ，幅約 $15 \mu$ 。刺狀細胞八蝶番細胞ノモノニテ長 サ $6,70 \mu$ 程度, 其他ノモノニテ長サ $60-100 \mu$ 。

裹面表皮 脈上細胞八長业 15-70 $\mu$ ，幅 10-15 $\mu$ ，薄膜。脈上以外／個所／表皮細

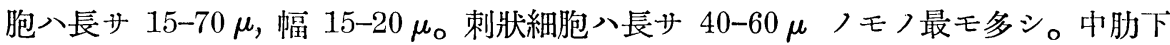
面ノ細胞八脈上ノモノ二似テ厚膜。

切斷面ニヨル觀察 蝶番細胞八中央部ノモノニテ高サ $30-40 \mu$, 外側ノモノハソノ中 程ノモノニテ最高凡り $60 \mu$ 。葉片八薄質乃至厚質。

せんだいすげ Carex sendaica Franchet in Bull. Soc. Philom. Paris 8 sér. 7 (1895) 42 。

表面表皮 蝶番細胞中央部ノモノ八長サ $30-40 \mu$ ，幅 15-20 $\mu$ ，外側ノモノ八長サ

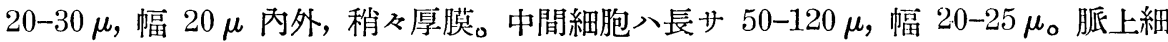
胞八一般二中間細胞二似, 一二ノ大脈中央部二テ長サ 10-60 $\mu$, 幅 $15 \mu$ Э內外ス。 刺狀細胞ハスベテ $7,80 \mu$ 程度ナり。

襄面表皮 脈上細胞八長サ 20-60 $\mu$ ，幅 $10 \mu$ 餘，其他ノ個所ノモノ八長サ 30-90 $\mu$, 幅 $15 \mu$ 內外。刺狀細胞八長サ $50 \mu$ 程度。氣孔入長サ $25 \mu$ 强, 幅 $25 \mu$ 弱二 シテ圓形ニ近シ。

緣邊細胞 刺狀細胞入長サ $100 \mu$ 餘ニ及ブモノ多シ。

切斷面ニヨル筧察 蝶番細胞中央部ノモノ八高サ $20 \mu$ 程度, 兩側ノモノ八最高 40 $\mu=$ 及ブ。葉片八薄質乃至厚質。

こごめなきりすげ Carex brunnea ThunberG： OHwI, Cyper. Jap. 1 (1936) 466 。

表面表皮 蝶番細胞中央部ノモノ八長サ 20-30 $\mu$, 幅 $20 \mu$ 內外，稍 $₹$ 厚膜，外側 部ノモノ八前者二似テ稍 $~$ 不齊形 フナス。中間細胞八長サ 40-100 $\mu$ (通常 $6,70 \mu$ ), 幅 $30 \mu$ 內外，著シク厚膜。脈上細胞八長サ (10-) 20-70 $\mu$ ，幅約 $15 \mu$ 。刺狀細胞 八長サ $50-100 \mu$ ノモノ最モ多シ。

裹面表皮 全部略々同形ノ細胞ヨリナリ，長サ 20-60 $\mu$ ，幅 $10 \mu$ 內外，厚膜。

じんぐうすげ Carex sacrosancta HondA in Bot. Mag. Tokyo 43 (1929) 190 (第二圖)。 


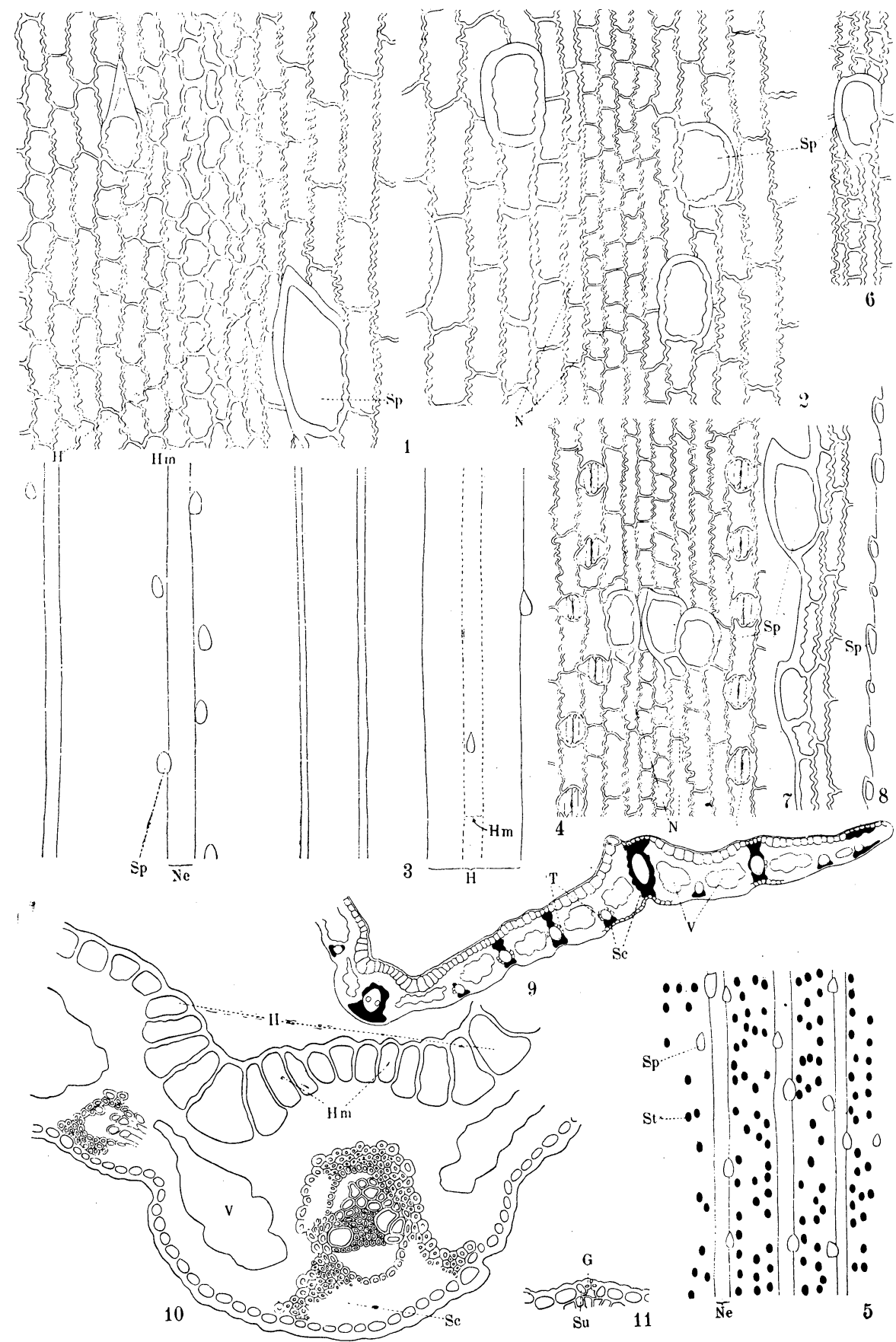

第一圖。なきりすげ（Carex Naliri）1. 表面表皮, 中央部。2. 司, 脈上及ビ中間細胞 條。3. 问, 及蝶番細胞條 7 示ス。 4 , 5. 襄面表皮, 脈上細細及ビ氣孔條。6. 中肋下泊。 
表面表皮 蝶番細胞ノ中央, 外側部ハトモ二小數列ノ細胞條ヨナシソノ差入輕微ナ リ，外側ノモノ八長サ 20-40 $\mu$ ，幅 $20 \mu$ 內外，細胞膜入厚クシテ緩ク波狀屈曲 ナス，中央部位ニテハ却ツテ不齊多角形ヨナシ徑 20-30 $\mu$ =シテ細胞膜八著シク厚 ク波狀屈曲微ナリ。中間細胞八長サ 50-100 $\mu$, 幅 20-30 $\mu$ ，厚膜。大脈中央部ノ細 胞入長サ 30-40 $\mu$, 幅 $10 \mu$ 內外, 薄膜, 其他ハスベテ中間細胞ト大差ナシ。刺狀細 胞八長正通例 $40-60 \mu$ 。

敦面表皮 脈上細胞條八左右片二五六ケ所アリテ表面ヨリモ著シク多キ事ナク,各 細胞八長サ 20-80 $\mu$, 幅 10-15 $\mu$, 厚膜，氣孔間ノモノ八脈上ノモノョリ稍々大形。 刺狀細胞極メテ稀ナリ。

切斷面ニヨル觀察 蛣番細胞八中央, 外側二分タル、事他ト同樣ナレドモソノ差著 シカラズ，高サ $50 \mu$ 习前後ス。某片八薄質。維管束八表裹兩方面二纎維习達スル モノ五六個所ニアリテ裹面ニノミ繊維ヨ有スルモノ少數ナリ。

むKんなきりすげ Carex Hattoriana NaKaI: Tuyama in Bot. Mag. Tokyo 49 (1935) 508, fig. 15 。

表面表皮 蝶番細胞八中央部ノモノニテ長少 15-40 $\mu$, 幅 $15 \mu$ 內外，細胞膜八厚 質ニシテ緩ク波狀屈曲ス，外側ノモノ八中央ノモノニ似テ不規則形 フナス。中間細 胞八長サ 40-80 $\mu$, 幅 20-40 $\mu$ ，厚膜，緩キ波狀屈曲膜习有ス。脈上細胞八長サ 15$40 \mu$, 幅 15-20 $\mu$, 厚膜。刺狀細胞八 50-80 $\mu$ ノモノ多シ。

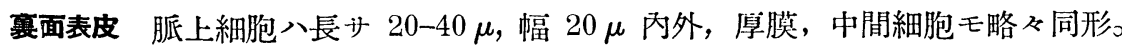
氣孔八棈圓形，長サ $30 \mu$, 幅 $25 \mu$, 强。刺狀細胞殆ドナシ。

切斷面ニヨル觀察 蝶番細胞八高サ中央部ニテ約 $30 \mu$, 外側部ノ中央ニテ $70 \mu=$ 及ブ。葉片八厚質。

おほなきりすげ Carex autumnalis OHwI in Mem. Coll. Sci. Kyoto Imp. Univ. ser. B, 5 (1930) 251 。

表面表皮 蝶番細胞中央部ノモノ八長サ 20-40 $\mu$, 幅 15-20 $\mu$, 稍飞厚膜, 外側部ノ モノ八齊形ヨナシ長サ幅トモ $=20-30 \mu$, 細胞膜八厚質ニシテ緩ク波狀屈曲ヨナス。 中間細胞八長サ $20-50 \mu$, 幅 $20 \mu$ 强, 脈上細胞八長サ 10-30 $\mu$, 幅約 $20 \mu$, スベテ 稍飞厚膜。刺狀細胞ノ長齐通常 50-90 $\mu_{\text {。 }}$

蔉面表皮 脈上細胞八通例氣孔條內外ノモノト同形ニシテ長サ 20-40 $\mu$, 幅 15-20 $\mu$ ナレドモ中二長サ $10-20 \mu$, 幅 $20 \mu$ 弱ノ小形ノモノモアリ, スベテ稍々厚膜。刺 狀細胞殆ドナシ。

切斷面ニヨル觀察 蝶番細胞中央部二テ高サ $15 \mu$ 內外，外側 ノ中央二テ約 $50 \mu$ 。 葉片入稍々厚質。中肋下面入殆ド全ク突出セズ。

7, 8. 緣澷。9. 葉片切斷面。1.0. 同, 中央部。11. 同, 氣孔部 $(3,5,8$ 及ビ 9 八 50 倍, 他八 200 倍)。

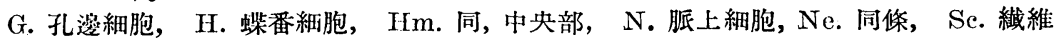
細胞， Sp. 刺狀細胞，St. 氧孔，Su。 孔周細胞，T. 交通細胞， V. 空胞。 
たかさごふさなきり Carex subteiogyna OHwI in Cyp. Jap. 2 (1936) 469 tab. $\mathrm{XV}$. (第三圖)。

表面表皮 蝶番細胞中央部ノモノ八他卜異ナリテ不齊長方形, 長サ 20- $40 \mu$, 幅 $20 \mu$
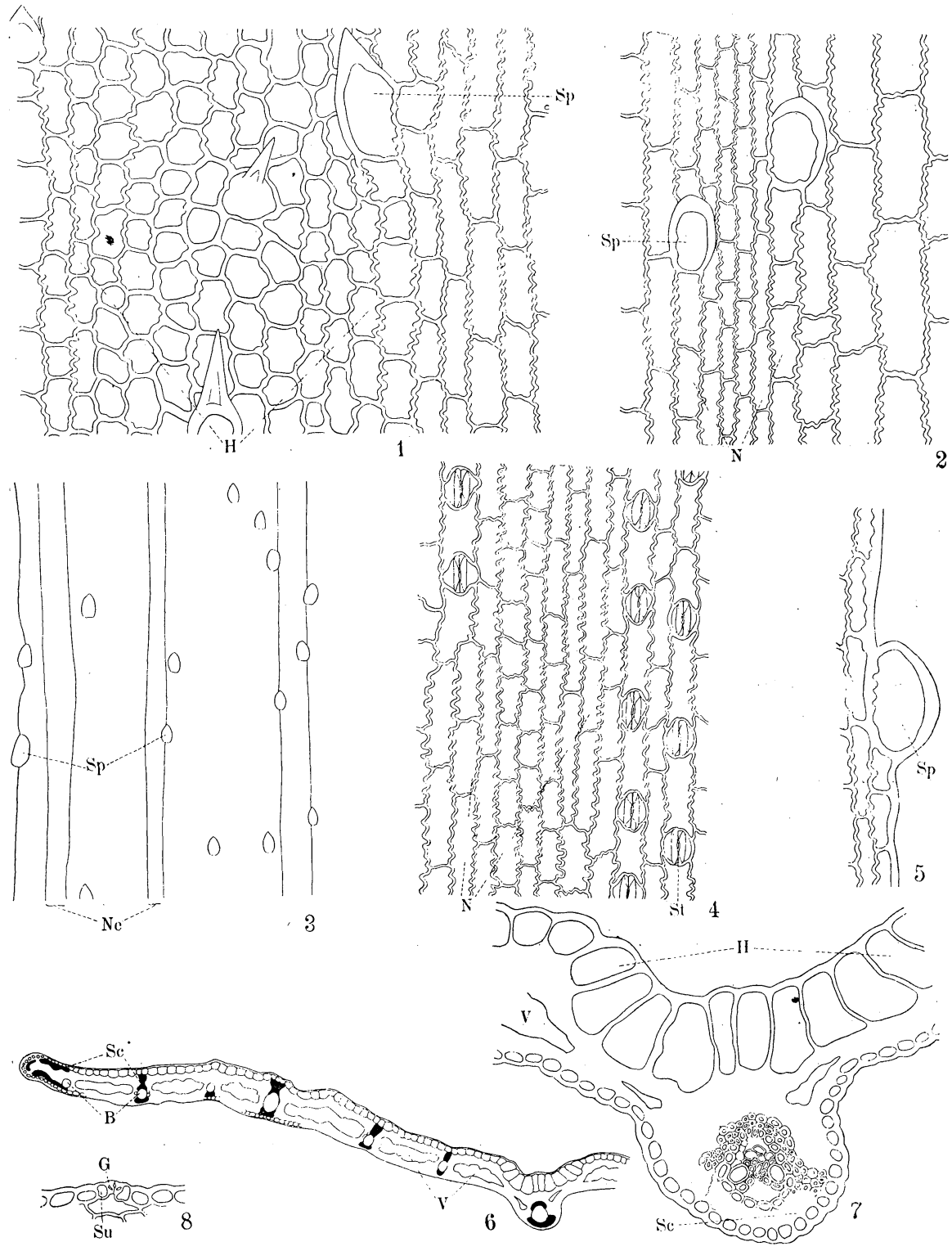

第二圖。じんぐうすげ（Carex sacrosancta）1. 表面表皮，中央部。2,3. 同，脈上及ビ

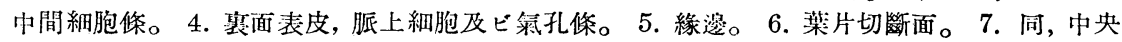
部, 8. 问, 氭孔部 $(3,6$ 八 50 倍, 他八全部 200 倍)。記號同前。 
內外，細胞膜八厚クシテ波狀屈曲殆ドナシ，外側部ノモノ八大小八前者二似テ更二

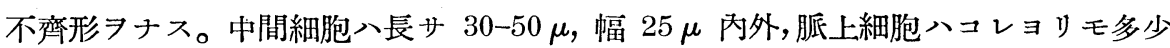

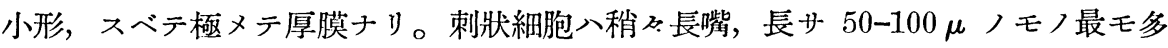
シ。

襄面表皮 脈上細胞八 $30-40 \mu$, 幅 $10 \mu$ 內外，氣孔間ノモノ八幅稍く大，スベテ 厚膜。脈上附近二表面ヨリ稍々小形ノ刺狀細胞アリ。

切斷面ニヨル觀察 蝶番細胞八スベテ高サ $3,40 \mu$ 程度。葉片八厚質。中肋下面稍 队突出ス。

ふさなきりすげ Carex scabriculmis OHwI in Acta Phytotax. et Geobot. 2 (1933) 27 。
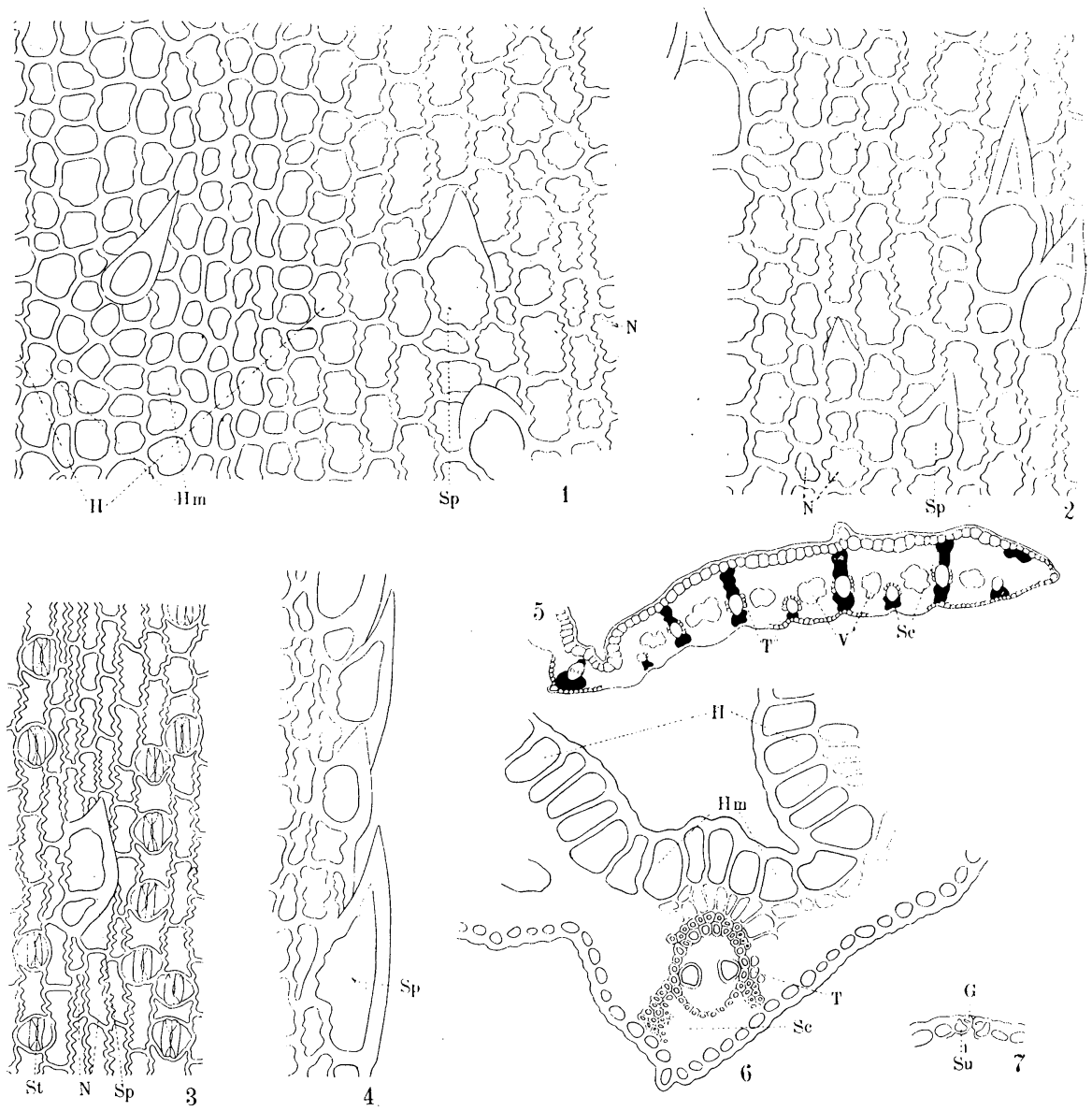

第三圖。たかさごふさなきり（Carex subteiogyna）1. 表面裴皮，中央部。2.问,脈上

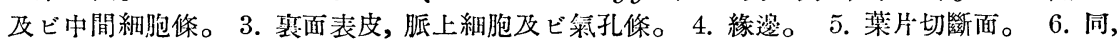
中央部。7. 同, 氣孔部（5 八50 倍, 他八全部 200 倍)。記號问前。 


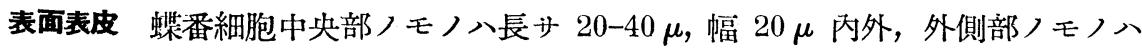
稍々不齊形，長サ 20-30 $\mu$ ，幅 $15 \mu$ 內外，スベテ細胞膜八厚質ニシテ緩ク波狀屈曲 ス。中間細胞八長サ 30-70 $\mu$, 幅 $20 \mu$ 弱, 稍々厚膜。脈上細胞八長サ 10-30 $\mu$, 幅 $10 \mu$ 內外。刺狀細胞八長文 $50-100 \mu$ 。

裏面表皮 脈上細胞八長サ 10-30 $\mu$, 幅 $15 \mu$ 內外。氣孔間ノモノ八長サ 20-50 $\mu$ ， 幅 $10 \mu$ 內外二テ小形。氣孔入長サ $25 \mu$, 幅 $20 \mu$ 。刺狀細胞殆ドナシ。

切糍面ニヨル観察 蝶番細胞中央部ニテ高サ $40 \mu$ 內外，外側部ノ中央ニテ $60 \mu$ 二達ス。葉片八稍《厚質乃至薄質。

北海道帝大理學部植物學教室

\section{Résumé.}

1. The leaves of following eight species belonging to Sect. Graciles are treated from the anatomical view point in this paper:

Carex Nakiri, C. sendaica, C. brunnea, C. sacrosancta, C. Hattoriana, C. autumnalis, C. subteiogyna and C. scabriculmis.

2. All these species resemble one another very much, and have common peculiar characteristics. Hinge cells form a central band and two lateral bands: cells of the central band are generally similar in their structures to the upper epidermal cells on the mesophyll or on the nerve, cells of the lateral band generally have thick and slightly wavy or smooth walls, like the hinge cells of many other Carices; larger and smaller vascular bundles generally alternate, and fibre cells stretch widely directly on inner sides of the upper epidermis as larger ones and below the under epidermis as smaller ones, and the fibre cells neighbouring the margin stretch conspicuously widely beneath the upper epidermis. Spine cells are found in all parts of the upper epidermis excepting the lateral bands of the hinge cells, and the margins, though sparsely on the nerves of the under epidermis. 